\title{
Engineering geological investigations for evaluation of excavation method and stand-up time of the DK99-DK100 Jakarta - Bandung high-speed railway tunnel, Indonesia
}

\author{
Linda $\mathrm{Ali}^{1,2}$, I Gde Budi Indrawan ${ }^{1}$, and Hendarto Hendarto ${ }^{2}$ \\ ${ }^{1}$ Gadjah Mada University, Geological Engineering Department, 55281 Yogyakarta, Indonesia \\ ${ }^{2}$ Ministry of Public Works and Housing of Indonesia
}

\begin{abstract}
This paper presents the investigation of surface geology and subsurface engineering geology to analyze the excavation method and stand-up time of the DK99-DK100 Jakarta-Bandung high-speed railway Tunnel, Indonesia. Rock mass quality, tunnel excavation method, and stand-up time determined using Geological Strength Index (GSI), Basic Quality (BQ) systems, converted to Rock Mass Rating (RMR) and The Japan Society of Civil Engineering (JSCE) for comparison. The result shows that the study area consists of slightly to completely weathered andesite breccia and slightly weathered andesite lava. The rock masses at the tunnel elevation had very poor to poor quality and were associated with high weathering degrees. The recommended rock excavation method based on the GSI is digging. The recommended tunnel excavation method based on RMR is multiple drifts, top heading, and bench, while based on JSCE is bench cut method. The tunnel stand-up time is 30 minutes - 2 hours based on the RMR, while it is predicted to be unstable without support based on the BQ. The recommended design is expected to be applied effectively according to the geological conditions. It is expected to understand better the tunnel excavation method in poor rock masses, especially in Indonesia.
\end{abstract}

\section{Introduction}

The construction of the Jakarta-Bandung fast train is one of the national strategic projects to reduce congestion problems, air pollution, and travel time. The journey has taken a long time because of traffic jams and hilly areas shortened by using tunnel technology, and there are 12 tunnels, one of which is the DK 99-DK 100 tunnel with a tunnel length of $208 \mathrm{~m}$ (DK 99+820 to DK 100+050).

Design of the tunnel cut through mountainous areas consisting of various types of rocks layers and the influence of geological structure conditions. The condition of rock quality in each rock layer will affect what kind of tunnel excavation method is effectively applied. Therefore, it is necessary to conduct engineering geological investigations to obtain information on soil and rock mass characteristics, geological structures, and groundwater that may affect the construction site. The surface geological engineering mapping scale used is 1:4000 because, based on the level of accuracy and purpose, 1:5,000 to 1:25,000 for construction work, including excavation and construction materials [1].

An essential aspect in engineering geology is the condition of the rock mass at the site to be built. Engineering geological investigations of the rock mass are carried out on the surface and the subsurface and should be carried out at the beginning and during construction work. It is essential to ensure that field conditions are under the initial design and adjustments are made when necessary [2].

Rock mass quality analysis has been classified as surrounding rock class VI by the tunnel designer. However, based on the high uncertainty that may arise in rock masses classification, other methods' analysis needs to be compared. In this study, rock mass classification was carried out using Geological Strength Index (GSI) and Basic Quality (BQ) System, which is juxtaposed with the Rock Mass Rating (RMR) as mutually reinforcing indicators. The authors choose The GSI classification because it is easy to use in field observations and poor rock conditions due to prominent tectonic influences and high weathering rates suitable for use in research locations dominated by volcanic rock affected by tectonic processes. The excavation method is also determined by the empirical approach based on the Japanese classification Society of Civil Engineers (JSCE). The expected results of the excavation method and stand-up time in the DK 99 - DK 100 tunnel design are appropriate according to the geological conditions found in the field.

The research area is administratively located in Nyalindung Village, District Cipatat, West Bandung Regency, West Java Province, Indonesia; the location can be seen in Figure 1. 


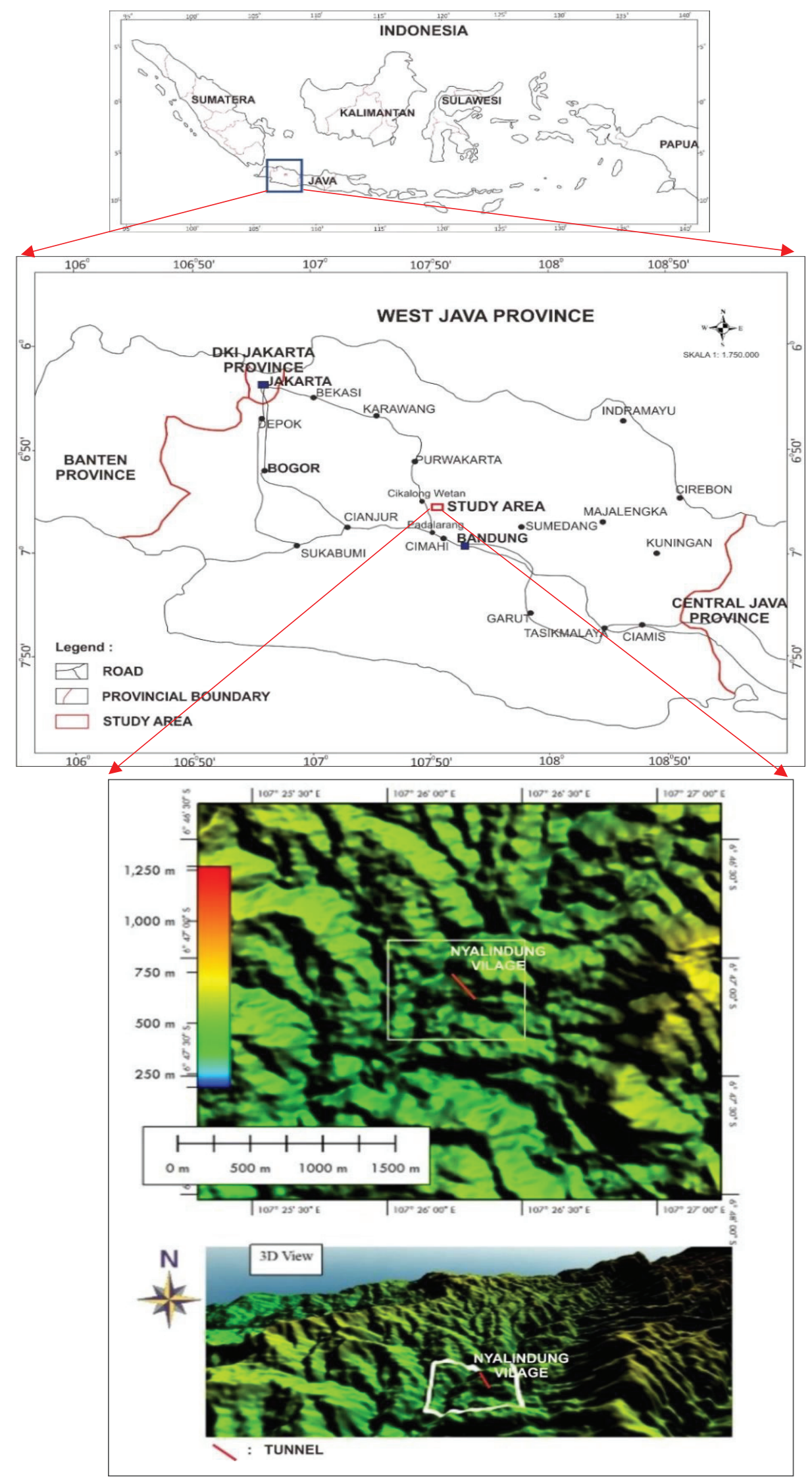

Fig. 1. Research area in West Java Province, Indonesia. 


\section{Methodology}

The research includes surface geological mapping and subsurface engineering geological mapping. The surface geological mapping was carried out by megascopic observations of the rock outcrops in the field. The subsurface engineering geological mapping is carried out by tunnel face mapping and observing the drilling and correlating rock mass layers to develop a geological engineering profile. Rock mass weathering degree was determined based on the International Society for Rocks Mechanics, ISRM method [3].

Classifications of subsurface rock masses were carried out based on the GSI, BQ-System, and JSCE. The GSI determination was based on the rock description in the face mapping using GSI basic chart by Marinos \& Hoek (2000), and core drill along the tunnel alignment with an assessment of the very poor rock masses using the GSI Index [4] by considering Broken Structural Domain (BSTR) and the Joint Condition Index (IJc) by the equation (1)

$$
I j c=(b s)+(W / 2)+4
$$

Ijc is Joint Condition Index, bs is the value of Broken Structural Domain (BSTR), and W is the filling and weathering condition of the core material.

The GSI measurements at the tunnel elevation from face mapping and core drill analysis were converted into RMR by the equation (2) [4] about correlation GSI and RMR for poor and very poor rock mass [5].

$$
R M R=20 I n(G S I / 6)
$$

The rock mass classifications based on BQ-System using two parameters: Rc and Kv, [6], [7], [8] and can be calculated based on the formula [8] as shown in equation (3) and (4) for BQ-Correction

$$
\begin{aligned}
& B Q=90+3 R c+250 K v \\
& {[B Q]=B Q-100\left(K_{1}+K_{2}+K_{3}\right)}
\end{aligned}
$$

Rc: Rock Strength (MPa) and Kv: Rock Mass Integrity $(\mathrm{Vpm}, \mathrm{km} / \mathrm{s})$ from the elastic longitudinal wave velocity of rock. $\mathrm{K}_{1}$ : correction coefficient for the influence of underground water, $\mathrm{K}_{2}$ : the correction coefficient for the influence of the orientation of the main weak structural planes, and $\mathrm{K}_{3}$ : the correction coefficient for the influence of the initial stress state. The BQ system values are converted into RMR by equation (5) [6].

$$
R M R=(B Q-80,79) /(6,09)
$$

Rock class/ category by the JSCE rock mass classification [9] requires a value of competence factor, determined by equation 6 .

$$
\text { Competence Factor }=q u /(\text { Y.H })
$$

qu: Unconfined compressive strength of the ground $\left(\mathrm{kN} / \mathrm{m}^{2}\right), \gamma$ : unit weight of the ground $\left(\mathrm{kN} / \mathrm{m}^{3}\right)$, and $\mathrm{H}$ : depth of cover (m).

The tunnel excavation method was determined [10] In addition to the RMR, the tunnel excavation method was also determined based on the Japan Society of Civil Engineering [9] for comparison. The rock excavation method is determined based on GSI value [11].

The determination of the stand-up time or the length of time the tunnel can last before the support system is installed uses two methods. The first method is based on the stand-up time chart developed [10] using the RMR correlation value from the GSI measurements. The second way is to use the stand-up time developed [8] based on the value of BQ.

\section{Results and discussions}

\subsection{Surface geological mapping}

Based on the regional geological map Sheet of Cianjur [12], the research area is influenced by the Older Volcanic Product Formation, consisting of breccia lahar, lava, volcanic breccia, flow breccia, and the composition is between andesite and basalt. The 1:4000 scale geological mapping showed the area formed by the andesite lava and andesite breccia rock unit. The breccia consists of andesite fragments from boulder to block size. The Geological map and profile are shown in Figure 2.

\subsection{Subsurface mapping \\ engineering geological}

Analysis of core drilling and correlation rock mass layer shows the tunnel path consists of four geological engineering units, namely slightly to completely weathered andesite breccias, as shown in Figure. 3.

Based on the tunnel subsurface engineering geological profile in Figure. 3. The tunnel elevation is located in two engineering geological rock units: completely weathered andesite breccia and highly weathered andesite breccia rock unit

The completely weathered andesite breccia, indicating that all the material has been wrecked and has turned into the soil; however, the rock mass structure can still be seen. The highly weathered andesite breccia rock unit, indicating more than half of the rock is crushed or turned into soil. Engineering geological characteristics of rock mass form of crushed stone, breccia as powder and soil and the specific weight are $15-17 \mathrm{kN} / \mathrm{m}^{3}$. 

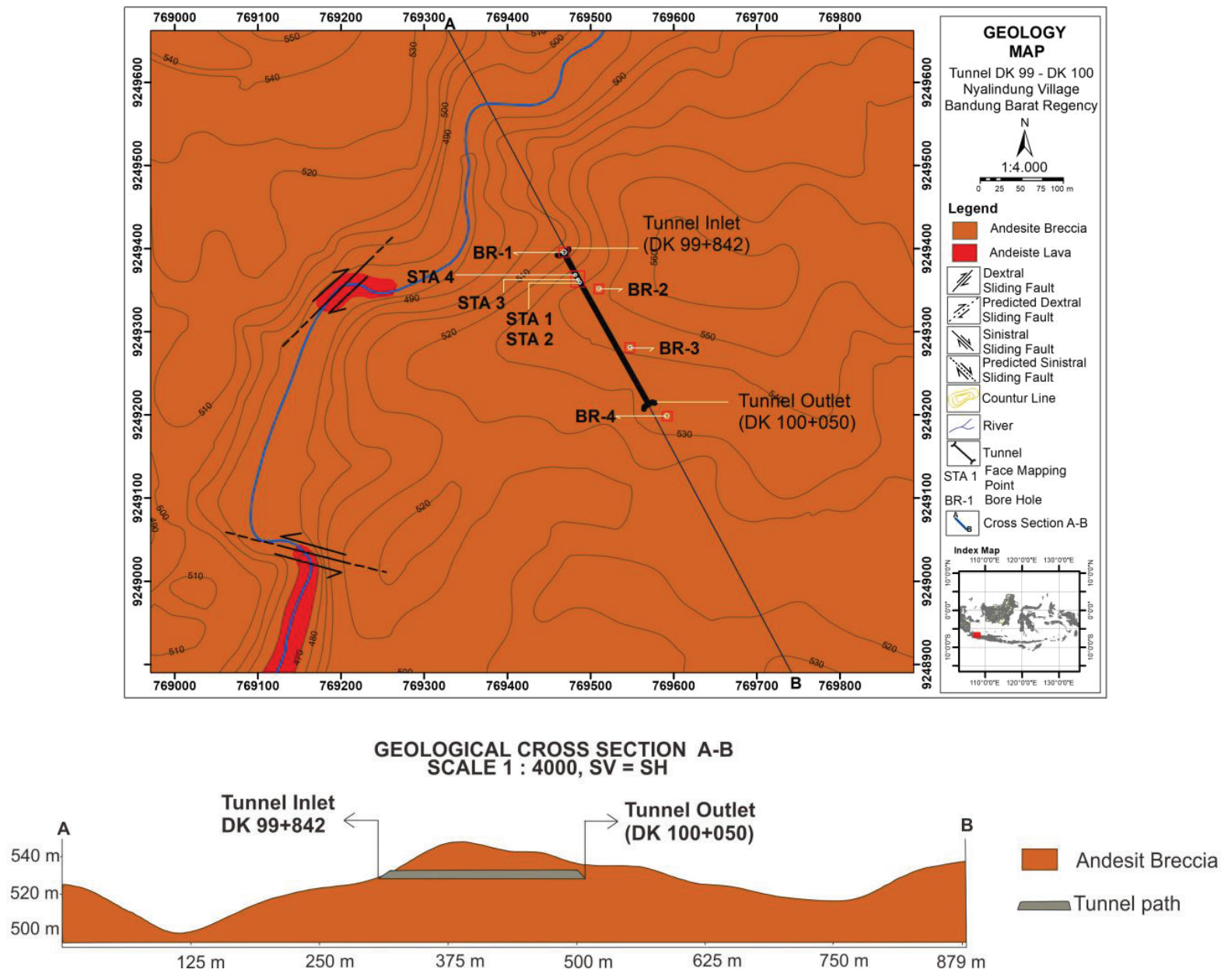

Fig. 2. Geological map and cross-section.

TUNNEL SUBSURFACE ENGINEERING GEOLOGICAL PROFILE SCALE $1: 500$

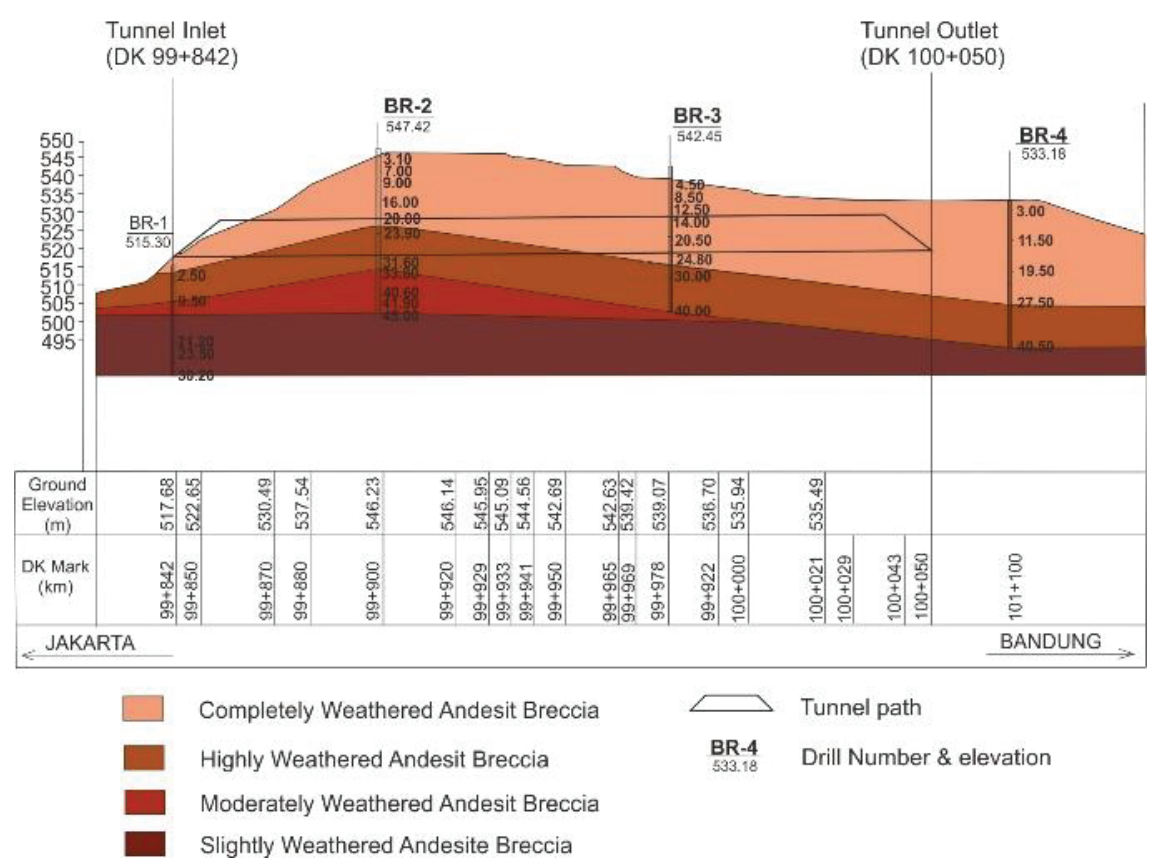

Fig. 3. Subsurface engineering geological profile of the tunnel path. 


\subsubsection{Geological strength index (GSI) classification}

Rock mass characterization at the face of the tunnel by face mapping along the tunnel DK99+879, DK 99+878, $99+876$, dan $99+869$ as many as four observation points: STA 1 at DK 99+879, STA 2 at DK 99+878, STA 3 at DK $99+876$, and STA 4 at DK $99+869$. The GSI

measurements are plotted on GSI basic chart [13] shown in Figure.4.

GSI values at the tunnel elevation were converted into RMR [4] about correlation GSI and RMR for poor and very poor rock mass are shown in Table 1 and Table 2 .

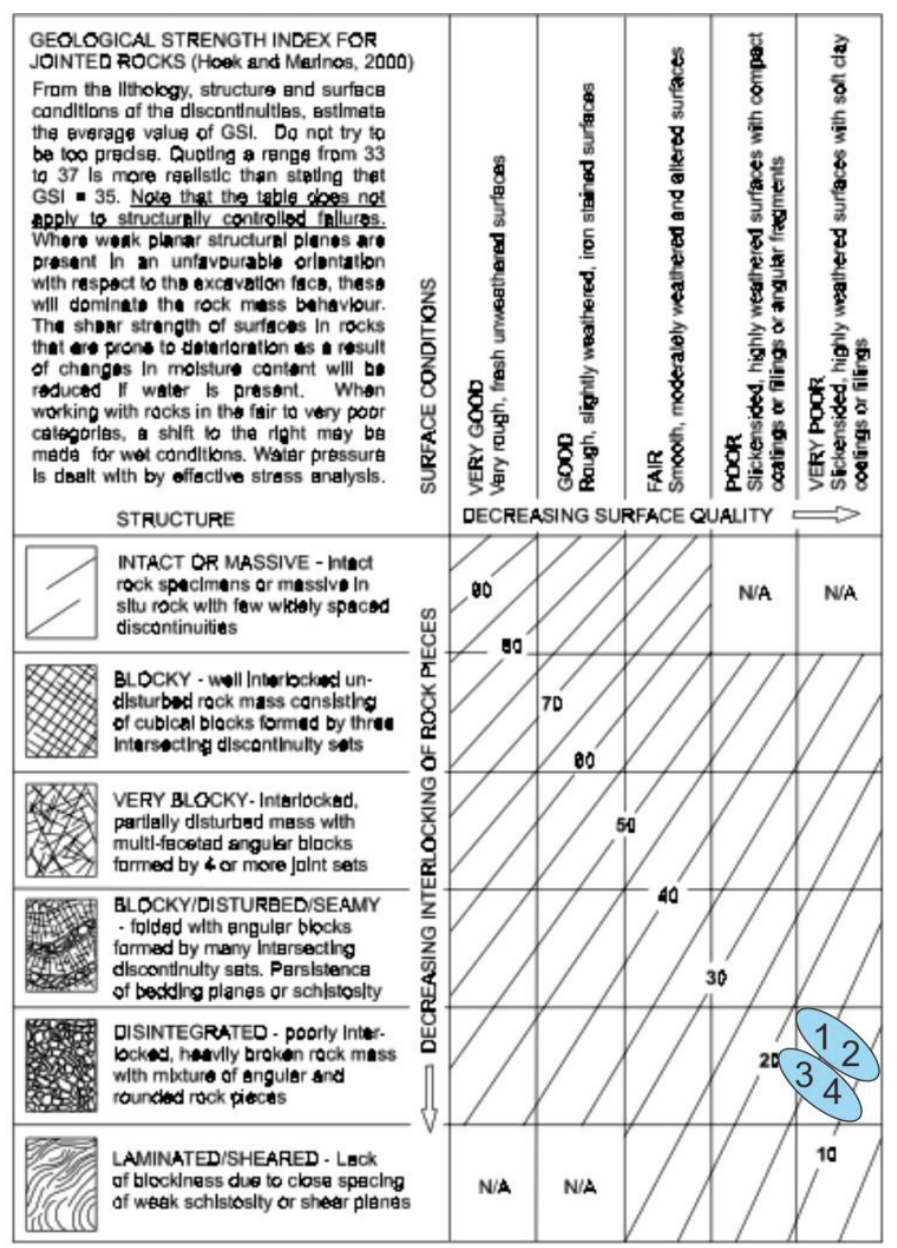

Fig. 4. GSI estimates from the geological face mapping observation on GSI chart [13].

Table 1. GSI and RMR result from face mapping at the tunnel elevation

\begin{tabular}{cccccc}
\hline No & $\begin{array}{c}\text { STA Face } \\
\text { Mapping }\end{array}$ & GSI & $\begin{array}{c}\text { Rock Mass Class } \\
\text { (Sivakaguan et.al 2013) }\end{array}$ & RMR & $\begin{array}{c}\text { Rock Mass Class } \\
\text { (Bieniawski, 1989) }\end{array}$ \\
\hline 1 & STA 1 & $10-15$ & Very Poor & $10.2-18.3$ & V $(<20)$ Very Poor \\
2 & STA 2 & $10-15$ & Very Poor & $10.2-18.3$ & V $(<20)$ Very Poor \\
3 & STA 3 & $10-15$ & Very Poor & $10.2-18.3$ & V $(<20)$ Very Poor \\
4 & STA 4 & $10-15$ & Very Poor & $10.2-18.3$ & $\mathrm{~V}(<20)$ Very Poor \\
\hline
\end{tabular}

Rock mass characterization of the core drill analysis consists of 4 points, namely BR 1 at DK 99+841.98, BR 2 at DK 99+898.23, BR 3 at DK 99+978.21, and BR 3 at DK $100+071.42$.
The range of GSI measurements using the GSI Index for very poor and poor rock charts [4] on core analysis in BR-2 at tunnel elevation by the equation (2) shows the GSI range from 11 to 26 as in Figure. 5. 


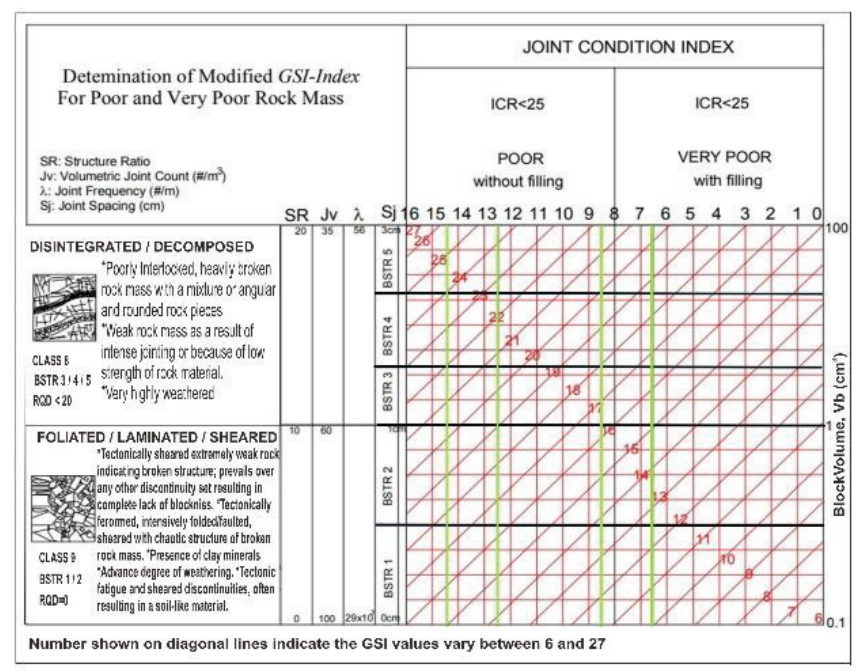

Fig. 5. GSI estimates from the core drill analysis by GSI Index for poor and very poor rock mass from [4].

Table 2. GSI and RMR result from core drill evaluation at the tunnel elevation

\begin{tabular}{|c|c|c|c|c|c|c|c|}
\hline No & Borehole & $\begin{array}{l}\text { Depth } \\
\text { (m) }\end{array}$ & BSTR & Ijc & GSI & RMR & Rock Mass Class \\
\hline 1 & BR-1 & $0-2.5$ & \multicolumn{2}{|c|}{ R0 Clayey Rock } & 0 & 0 & $\mathrm{~V}(<20)$ \\
\hline \multirow{6}{*}{2} & \multirow{6}{*}{ BR-2 } & & BSTR 1 & 6.5 & $11-12$ & $12.1-13.9$ & Very \\
\hline & & $20-25$ & BSTR 2 & 8.5 & $14-16$ & $16.9-19.6$ & Poor \\
\hline & & & BSTR 4 & 12.5 & $21-22$ & $25.1-26.0$ & \multirow{4}{*}{ IV (21 - 40) Poor } \\
\hline & & \multirow{3}{*}{$26-30$} & BSTR 3 & 10.5 & $17-18$ & $20.8-22$ & \\
\hline & & & BSTR 4 & 12.5 & $21-22$ & $25.1-26.0$ & \\
\hline & & & BSTR 5 & 14.5 & $24-26$ & $27.7-29.3$ & \\
\hline 3 & BR-3 & $13-24$ & \multicolumn{2}{|c|}{ R0 Clayey Rock } & 0 & 0 & \multirow{2}{*}{$\begin{array}{c}\text { V }(<20) \\
\text { Very } \\
\text { Poor }\end{array}$} \\
\hline 4 & BR-4 & $3-14$ & \multicolumn{2}{|c|}{ R0 Clayey Rock } & 0 & 0 & \\
\hline
\end{tabular}

Analysis of core drilling and correlation rock mass quality shows the tunnel path consists of three rock mass qualities from very poor, poor, and fair, as shown in Figure 6.
Based on the tunnel subsurface rock mass quality profile in Figure 6. The tunnel elevation is located in Very poor and poor rock mass quality.

TUNNEL SUBSURFACE ROCK MASS QUALITY PROFILE SCALE $1: 500$

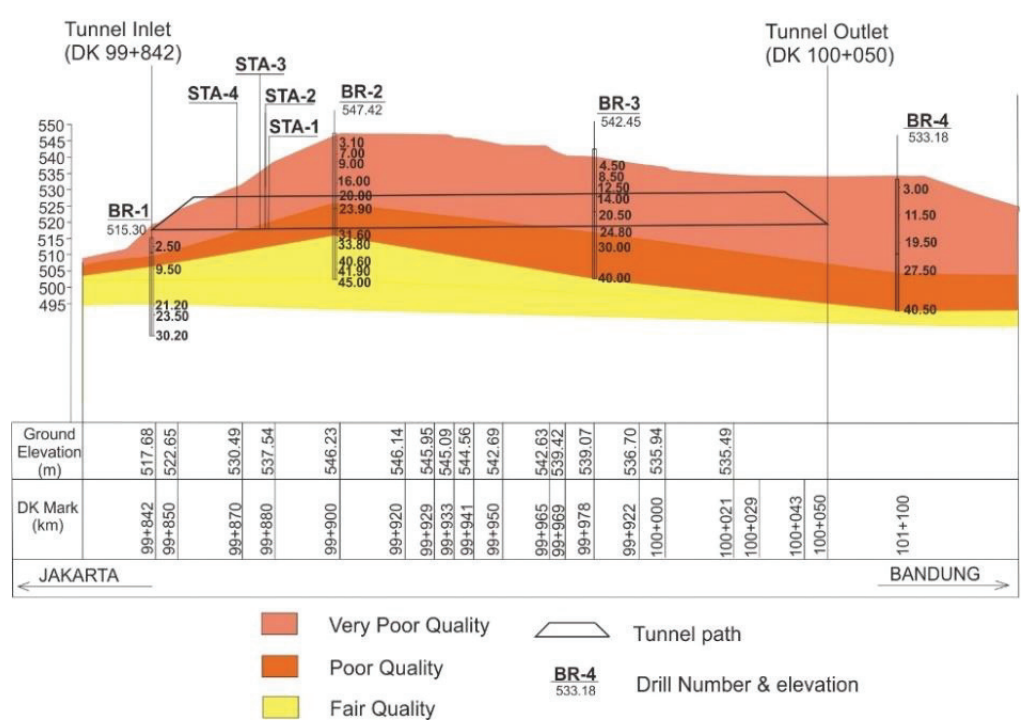

Fig. 6. Rock Mass Quality Profile of the tunnel path. 


\subsubsection{Basic Quality (BQ-System) classification}

The BQ system values are converted into RMR and the results are shown in Table 3. In determining the rock class based on the BQ value, the author uses references from the Professional Standard by the Ministry of Railway of the People's Republic of China in the Code for Design on Tunnel of Railway, which has accommodated weak rock conditions.

Table 3. BQ and RMR result.

\begin{tabular}{|c|c|c|c|c|c|}
\hline No & $\begin{array}{c}\text { STA, } \\
\text { Borehole \& } \\
\text { Depth }(\mathbf{m})\end{array}$ & BQ & $\begin{array}{c}\text { Rock Class } \\
\text { BQ Index (Feng \& } \\
\text { Hudson, 2011) } \\
\end{array}$ & RMR & $\begin{array}{c}\text { Rock Mass Class } \\
\text { (Bieniawski, 1989) }\end{array}$ \\
\hline 1 & STA 1 & $137-187$ & $\mathrm{~V}(<250)$ & $9.2-17.4$ & V $(<20)$ Very Poor \\
\hline 2 & STA 2 & $137-187$ & $\mathrm{~V}(<250)$ & $9.2-17.4$ & V $(<20)$ Very Poor \\
\hline 3 & STA 3 & $137-187$ & $\mathrm{~V}(<250)$ & $9.2-17.4$ & V $(<20)$ Very Poor \\
\hline 4 & STA 4 & $137-187$ & $\mathrm{~V}(<250)$ & $9.2-17.4$ & V $(<20)$ Very Poor \\
\hline 5 & $\begin{array}{l}\text { BR-1 } \\
(0-2.5)\end{array}$ & $115-143$ & $\mathrm{~V}(<250)$ & $5.6-10.2$ & V $(<20)$ Very Poor \\
\hline 6 & $\begin{array}{c}\text { BR-2 } \\
(20-30)\end{array}$ & $149-211$ & $\mathrm{~V}(<250)$ & $11.2-21.4$ & IV (21-40) Poor \\
\hline 7 & $\begin{array}{c}\text { BR-3 } \\
(13-24)\end{array}$ & $115-143$ & $\mathrm{~V}(<250)$ & $5.6-10.2$ & V $(<20)$ Very Poor \\
\hline 8 & $\begin{array}{l}\text { BR-4 } \\
(3-14)\end{array}$ & $115-143$ & $\mathrm{~V}(<250)$ & $5.6-10.2$ & V $(<20)$ Very Poor \\
\hline
\end{tabular}

\subsubsection{Japan Society of Civil Engineering (JSCE, 2007) classification}

Rock class/ category by the JSCE classification [3] requires a value of competence factor and the results are shown in Table 4.

In determining the rock class based on the JSCE, the author uses JSCE ground classification [9], which has been adopted as Guidelines for Excavation Planning Methods and Road Tunnel Strengthening System in Mixed Soil - Rock Media by the Ministry of Public Works and Public Housing of Indonesia [14]. Rock mass class $\mathrm{E}$ is classified with poor rock condition, and DII shows the rock with strong weathering, cores form of small pieces, sometimes form of clay, and with mixed rock fragment.

Table 4. JSCE Rock Class/Category result

\begin{tabular}{|c|c|c|c|c|}
\hline No & STA \& Borehole & Depth (m) & Competence Factor & Rock Class/ Category \\
\hline \multirow{4}{*}{1} & \multirow{3}{*}{ STA 1} & 8.5 & 0.65 & $\mathrm{E}$ \\
\hline & & 16 & 1.12 & DII \\
\hline & & 18.5 & 1.31 & DII \\
\hline & \multirow{3}{*}{ STA 2} & 7.5 & 0.53 & $\mathrm{E}$ \\
\hline \multirow[t]{3}{*}{2} & & 16 & 1.27 & DII \\
\hline & & 17.5 & 1.48 & DII \\
\hline & \multirow{4}{*}{ STA 3} & 6 & 0.53 & $\mathrm{E}$ \\
\hline \multirow[t]{3}{*}{3} & & 9 & 0.93 & $\mathrm{E}$ \\
\hline & & 16 & 1.59 & DII \\
\hline & & 2.5 & 0.73 & $\mathrm{E}$ \\
\hline \multirow[t]{2}{*}{4} & \multirow[t]{2}{*}{ STA 4} & 7 & 0.58 & $\mathrm{E}$ \\
\hline & & 12.5 & 0.73 & $\mathrm{E}$ \\
\hline \multirow[t]{2}{*}{5} & \multirow[t]{2}{*}{ BR-1 } & & Under the tunnel e & vation \\
\hline & & 18 & 0.98 & $\mathrm{E}$ \\
\hline \multirow[t]{3}{*}{6} & \multirow[t]{3}{*}{ BR-2 } & 23.9 & 1.91 & DII \\
\hline & & 28 & 1.64 & DII \\
\hline & & 11.5 & 0.24 & $\mathrm{E}$ \\
\hline \multirow[t]{2}{*}{7} & \multirow[t]{2}{*}{ BR-3 } & 20.5 & 0.84 & $\mathrm{E}$ \\
\hline & & 21.5 & 0.83 & $\mathrm{E}$ \\
\hline 8 & BR-4 & & Outside the tunnel $\mathrm{e}$ & vation \\
\hline
\end{tabular}




\subsection{Excavation method}

\subsubsection{Rock excavation method}

The rock excavation method based on the GSI value is shown in Figure. 7 and Table 5. GSI value and point load index are required to use this classification [11]. Based on the classification chart Is $50>3 \mathrm{Mpa}$, and the Value of GSI $10-26$, the result shows the rock excavation method from tunnel outlet until tunnel inlet is Digging.

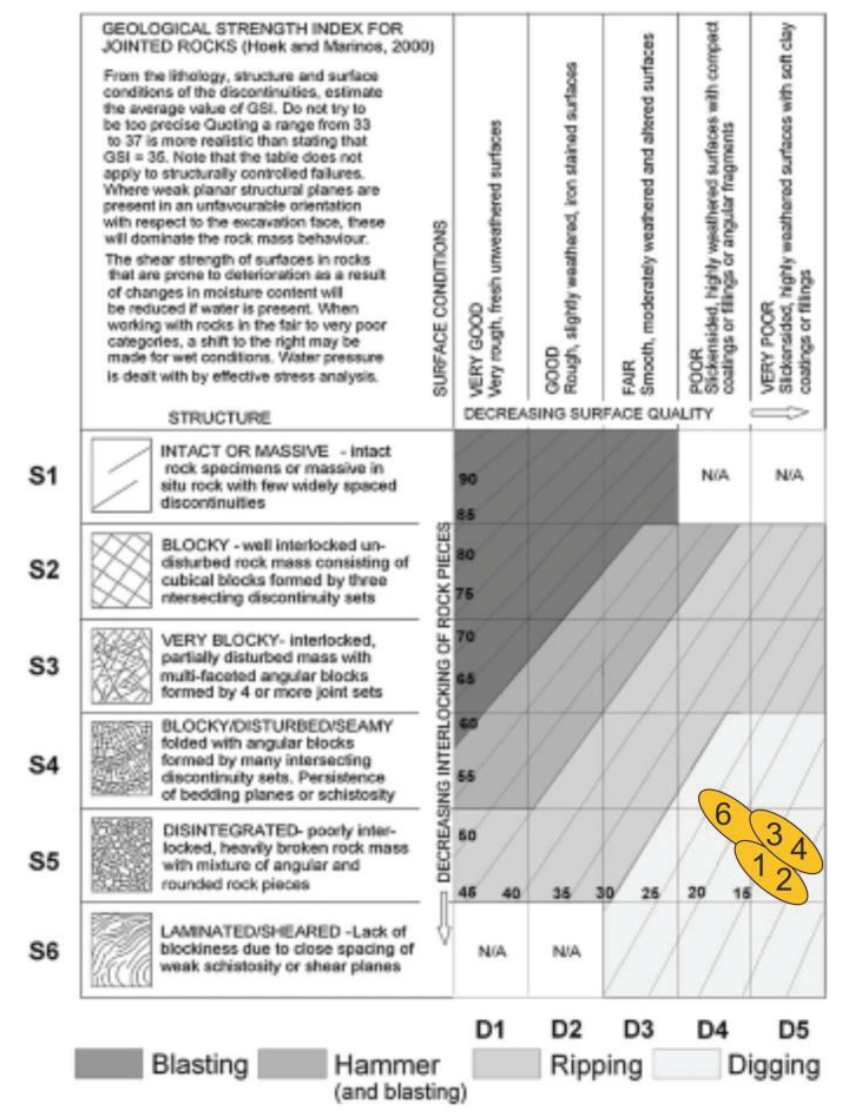

Fig. 7. Plotting GSI value in GSI rock excavation chart [11].

Table 5. Rock Excavation Method based on GSI value.

\begin{tabular}{|c|c|c|c|c|}
\hline No & $\begin{array}{l}\text { STA \& Borehole } \\
\text { (DK) }\end{array}$ & Rock Type & GSI & $\begin{array}{l}\text { Rock Excavation Method } \\
\text { (Tsiambos \&Sroglou, 2009) }\end{array}$ \\
\hline 1 & $\begin{array}{c}\text { STA 1 } \\
\text { (DK 99+879) }\end{array}$ & & $10-15$ & Digging \\
\hline 2 & $\begin{array}{c}\text { STA 2 } \\
\text { (DK 99+878) }\end{array}$ & & $10-15$ & Digging \\
\hline 3 & $\begin{array}{c}\text { STA } 3 \\
(\text { DK } 99+876)\end{array}$ & & $10-15$ & Digging \\
\hline 4 & $\begin{array}{c}\text { STA } 4 \\
\text { (DK 99+869) }\end{array}$ & $\begin{array}{l}\text { Andesite } \\
\text { Breccia }\end{array}$ & $10-15$ & Digging \\
\hline 5 & $\begin{array}{c}\text { BR-1 } \\
\text { (DK99+841.98) }\end{array}$ & $\begin{array}{l}\text { Completely } \\
\text { Weathered }\end{array}$ & \multicolumn{2}{|c|}{ Under the tunnel elevation } \\
\hline 6 & $\begin{array}{c}\text { BR-2 } \\
(\text { DK99+898.23) }\end{array}$ & & $\begin{array}{l}10-22 \\
17-26\end{array}$ & $\begin{array}{l}\text { Digging } \\
\text { Digging }\end{array}$ \\
\hline 7 & $\begin{array}{c}\text { BR-3 } \\
\text { (DK99+878.21) }\end{array}$ & & R0 (Clayey Rock) & Digging \\
\hline 8 & $\begin{array}{c}\text { BR-4 } \\
(\mathrm{DK} 100+071.42)\end{array}$ & & \multicolumn{2}{|c|}{ Outside the tunnel track } \\
\hline
\end{tabular}




\subsubsection{Tunnel excavation method}

Tunnel excavation methods $[9,10]$ shown in Table 6. The recommended tunnel excavation method is divided into two sections based on rock mass quality at the tunnel path. Section one: DK 99+842 - DK 99+875 and DK $99+965$ - DK $100+050$ based on RMR is multiple drifts $0,5-1,5 \mathrm{~m}$ advance in the top heading. Section two: DK $99+875$ - DK $99+965$ is top heading and bench, advancing $1,0-1,5 \mathrm{~m}$ on top heading. Based on JSCE, multiple benches cut method from tunnel outlet (DK 100+050) until tunnel inlet (DK 99+842) as shown in Figure. 8. Multiple benches cut methods are shown in Figure. 9.

Table 6. Excavation method based on RMR and JSCE rock mass classifications.

\begin{tabular}{|c|c|c|c|}
\hline \multirow[b]{2}{*}{ No } & \multirow{2}{*}{$\begin{array}{c}\text { STA \& } \\
\text { Borehole } \\
\text { DK }(\mathbf{k m})\end{array}$} & \multicolumn{2}{|c|}{ Excavation Method } \\
\hline & & JSCE & RMR \\
\hline 1 & $\begin{array}{c}\text { STA 1 } \\
\text { (DK 99+879) }\end{array}$ & \multirow{3}{*}{$\begin{array}{l}\text { Bench Cut Method (Multiple } \\
\text { Bench Cut Method) }\end{array}$} & \multirow{4}{*}{$\begin{array}{l}\text { Multiple drifts } 0,5-1,5 \mathrm{~m} \text { advance in } \\
\text { the top heading. Install support } \\
\text { concurrently with excavation }\end{array}$} \\
\hline 2 & $\begin{array}{c}\text { STA 2 } \\
\text { (DK 99+878) }\end{array}$ & & \\
\hline 3 & $\begin{array}{c}\text { STA 3 } \\
\text { (DK 99+876) }\end{array}$ & & \\
\hline 4 & $\begin{array}{c}\text { STA } 4 \\
\text { (DK 99+869) }\end{array}$ & \multirow{2}{*}{\multicolumn{2}{|c|}{ Under the tunnel elevation }} \\
\hline 5 & $\begin{array}{c}\text { BR-1 } \\
\text { (DK99+841.98) }\end{array}$ & & \\
\hline 6 & $\begin{array}{c}\text { BR-2 } \\
(\mathrm{DK} 99+898.23)\end{array}$ & $\begin{array}{l}\text { Bench Cut Method (Multiple } \\
\text { Bench Cut Method) }\end{array}$ & $\begin{array}{l}\text { Top heading and bench } 1,0-1,5 \mathrm{~m} \\
\text { advance in the top heading. Install } \\
\text { support currently with excavation } 10 \mathrm{~m} \\
\text { from the face }\end{array}$ \\
\hline 7 & $\begin{array}{c}\text { BR-3 } \\
(\mathrm{DK} 99+878.21)\end{array}$ & $\begin{array}{l}\text { Bench Cut Method (Multiple } \\
\text { Bench Cut Method) }\end{array}$ & $\begin{array}{l}\text { Multiple drifts } 0,5-1,5 \mathrm{~m} \text { advance in } \\
\text { the top heading. Install support } \\
\text { concurrently with excavation }\end{array}$ \\
\hline 8 & $\begin{array}{c}\text { BR-4 } \\
(\mathrm{DK} 100+071.42)\end{array}$ & \multicolumn{2}{|c|}{ Outside the tunnel track } \\
\hline
\end{tabular}

TUNNEL SUBSURFACE ROCK MASS QUALITY PROFILE SCALE 1: 500

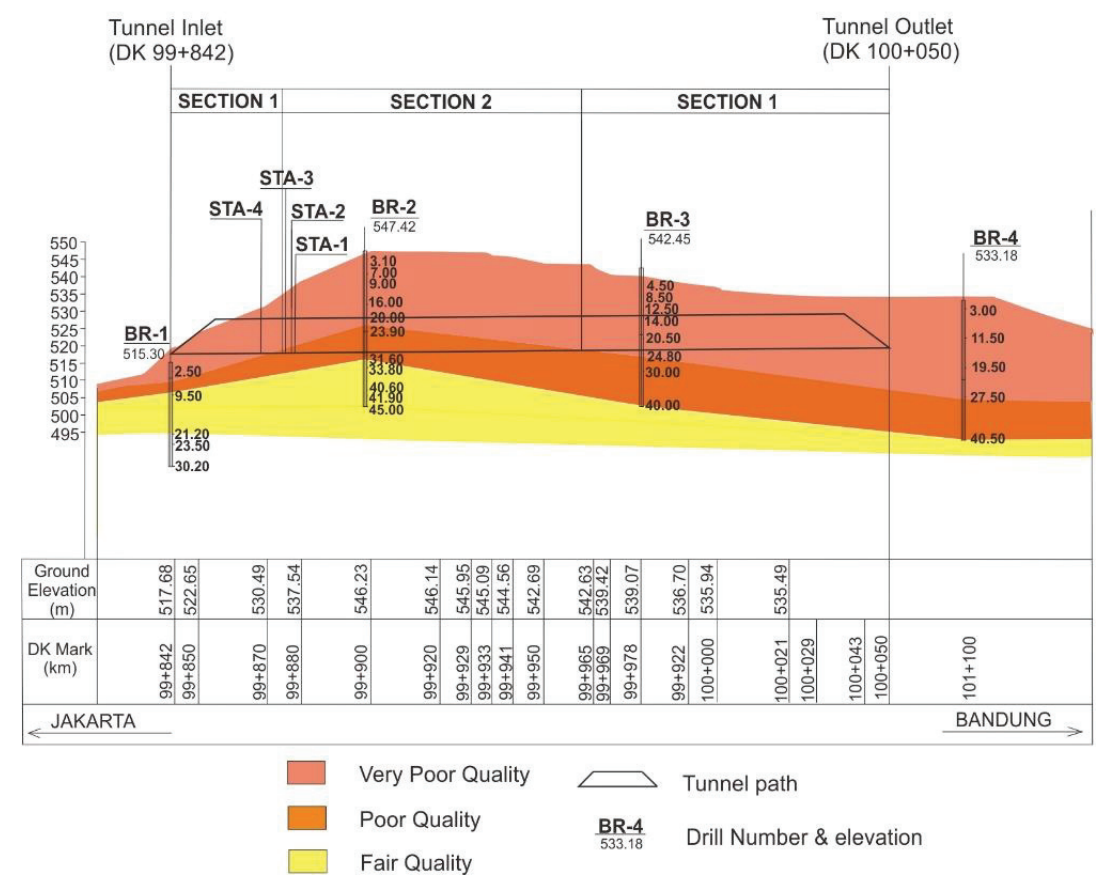

Fig. 8. The Section is divided based on rock mass quality at the tunnel elevation. 


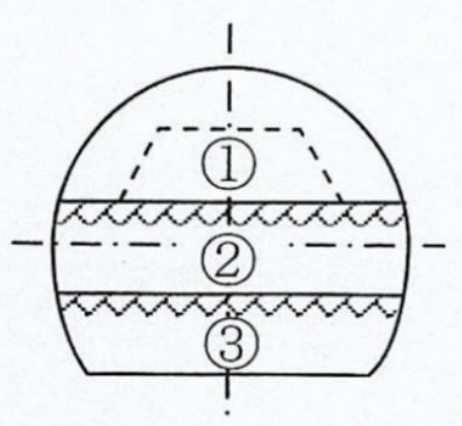

Fig. 9. Bench cut method (Multiple Bench Cut Method) [9] rock class/ category E and DII

The advantage of the Bench cut method / Multiple benches cut method (double bench) excavation method is that the face of the excavation area can be easy to stabilize.

\subsection{Stand-up time}

Stand-up time or time that a tunnel will stand unsupported after excavation was determined based on RMR value with unsupported roof span [10] as shown in Figure 10. Mark "A" show unsupported roof span is the width of the tunnel: $12,6 \mathrm{~m}$, while Mark "B" shows unsupported roof span is the distance from the face to the support by face mapping data: $1,2 \mathrm{~m}$ and Stand-up time based on BQ [8] as shown in Table 7 and 8 .

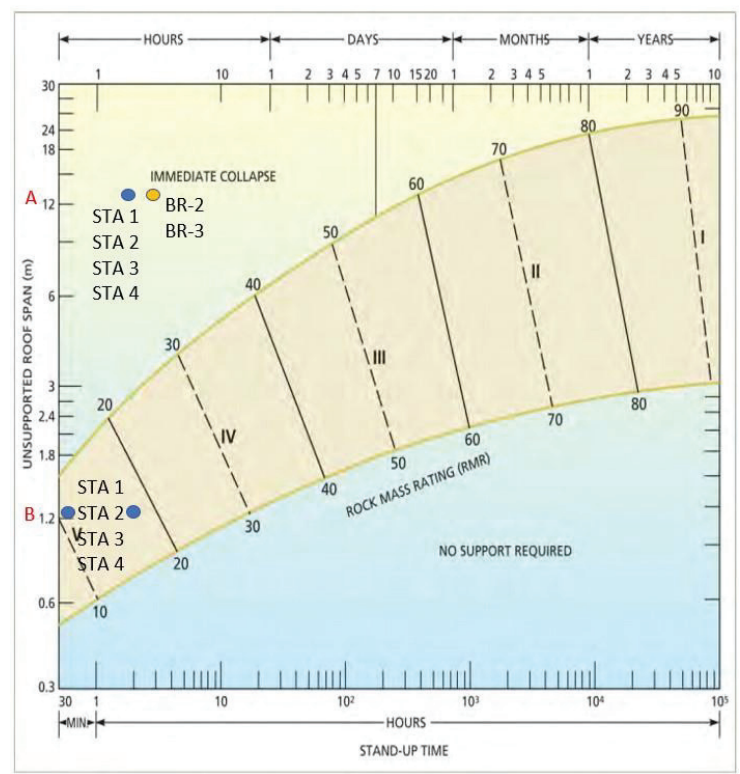

Fig. 10. Plotting RMR Value and Unsupported roof span [10]

Table 7. Tunnel stand-up time based on face mapping data.

\begin{tabular}{ccccc}
\hline No & $\begin{array}{c}\text { STA Face } \\
\text { Mapping }\end{array}$ & $\begin{array}{c}\text { RMR with a span of } \\
\text { the 12,6 meters }\end{array}$ & $\begin{array}{c}\text { RMR with a span of the 1,2 } \\
\text { meters from face mapping data }\end{array}$ & BQ System \\
\hline \multirow{2}{*}{1} & $\begin{array}{c}\text { STA 1 } \\
\text { (DK 99+879) } \\
\text { STA 2 }\end{array}$ & & & \\
2 & (DK 99+878) & Class V (Not \\
& STA 3 & Immediate Collapse & 30 min - 2 hours & $\begin{array}{c}\text { Stable without } \\
\text { support or } \\
\text { reinforcement) }\end{array}$ \\
4 & $\begin{array}{c}\text { (DK 99+876) } \\
\text { STA 4 } \\
\text { (DK 99+869) }\end{array}$ & & \\
\hline
\end{tabular}

Table 8. Tunnel stand-up time based on core drill evaluation.

\begin{tabular}{|c|c|c|c|}
\hline \multirow{2}{*}{ No } & \multirow{2}{*}{ Borehole } & \multicolumn{2}{|c|}{ Stand-up Time } \\
\hline & & RMR with a span of the 12,6 meters & BQ System \\
\hline 1 & $\begin{array}{c}\text { BR-2 } \\
(\mathrm{DK} 99+898.23)\end{array}$ & \multirow[t]{2}{*}{ Immediate Collapse } & \multirow{2}{*}{$\begin{array}{c}\text { Class V (Not Stable } \\
\text { without support or } \\
\text { reinforcement) }\end{array}$} \\
\hline 2 & $\begin{array}{c}\text { BR-3 } \\
\text { (DK99+878.21) }\end{array}$ & & \\
\hline
\end{tabular}

The controlling factor that influences the engineering geology conditions in the study area is the rock weathering degree. The geological control of the rock mass quality is the structure of the rock mass and the level of weathering, which plays an important role.

Very poor and poor rock mass quality in the tunnel path because the rock condition has undergone complete weathering. All rock material is crushed and turned into soil, but the rock mass structure can be seen; the rock mass structure shows disintegrated and poorly interlocked.

Very poor and poor rock mass quality in the research site located at a higher elevation or in hilly areas, at the same time, the decreasing depth indicates the rock mass quality is starting to improve with moderate quality structural conditions tend to be massive and slightly weathered, found in areas with elevation relatively low or flat and in areas along the river. 
Another consideration is the research area regionally consisting of quaternary deposits and volcanic debris. The thickness of this quarterly deposit in regional formations [12] is estimated to be around $150 \mathrm{~m}$. The tectonic setting of the West Java region can also be considered where there is an active fault to the south of the study area, causing the area to become a weak zone that affects the quality of rock mass.

The tunnel position is in poor to very poor rock mass quality, and it would be ideal if the tunnel is in a rock layer with very good quality. Therefore, it is necessary to pay attention to the calculation of tunnel elevation, design water discharge, overburden thickness, and load above the tunnel.

\section{Conclusion}

The study area consists of two rock units: andesite breccia and andesite lava rock unit. Rock weathering degree consists of slightly to completely weathered andesite breccia and slightly weathered andesite lava. The tunnel path is located at an andesite breccia rock unit with a completely weathered degree. The rock masses quality at the tunnel elevation consists of: very poor quality $(\mathrm{GSI}<20$, RMR $<20$ Class V, BQIndex $<250$, JSCE Class DII \& E) and poor quality (GSI: 21-40, RMR: 21-40, BQ-Index $<250$, JSCE Class DII \& E) controlled by the weathering degree of the rock. The tunnel position is in poor to very poor rock mass quality; under these conditions, the position of the tunnel can still be maintained by paying attention to the calculation of tunnel elevation, design water discharge, overburden thickness, and load above the tunnel.

The recommended rock excavation method based on GSI for DK99+842-DK100+050 is ripping. Recommended tunnel excavation method Based on RMR can be divided into two sections: section one on DK 99+842 - DK 99+875 and DK 99+965 - DK $100+050$ is multiple drifts $0.5-1.5 \mathrm{~m}$ in front of top heading, and section two on DK 99+875 - DK 99+965 is top heading and bench, advancing $1.0-1.5 \mathrm{~m}$ on top heading, while based on JSCE it is multiple benches cut method from Tunnel Outlet (DK 100+050) - tunnel inlet (DK 99+842). Both excavation methods divide the excavated face into several benches to make it easy to carry out the necessary stabilization.

The tunnel is predicted to be unstable without support based on the $\mathrm{BQ}$, while the tunnel stand-up time is 30 minutes -2 hours based on the RMR. The RMR and $\mathrm{BQ}$ values in determining stand-up time show recommendations that are not much different. The stand-up time is short, and it is recommended to install the support system immediately after being excavated, so the correlation equation used is considered appropriate.

The authors would express gratitude to PT. Kereta Cepat Indoensia China (KCIC), PT. China Railway Engineering Corporation (CREC) and PT. China Railway Design Corporation (CRDC) for research permit and data access permission. The first author would also like to thank The
Ministry of Public Works and Housing of Indonesia for the scholarship for the Master Study Program.

\section{References}

1. G. De Vallejo, \& M. Ferrer, Geological Engineering (CRC Press, 2011).

2. Sugalang, Engineering geology guide (Ministry of Energy and Mineral Resources, Center for Groundwater Resources and Environmental Geology, Geological Agency, 2016)

3. ISRM, Int. J. Rock Mech, Sci.\& Geomech. 15(6), 319-368 (1978)

4. R. Osgoui and E. Unal, Characterization of Weak Rock Masses Using GSI-Index and the Estimation of Support-Pressure, in the - 40th US Rock Mechanics Symposium (2005)

5. Zhang Q Huang X, Zhu H, Li J 2019, Tunn. Undergr. Sp. Tech. 83, 73-81 (2019)

6. M. Wang, Z. Wang, J. Tong, X. Zhang, Y. Dong, D. Liu, Jurnal of Central South University 28(1), 247-263 (2021)

7. Ministry of Railways of the People's Republic of china, Code for Design on Tunnel of Railway, in Professional Standard of the people's republic of China, TB10003- p 100, (2005)

8. X. Feng, J. Hudson, Rock Engineering Design, (CRC Press, 2011)

9. Japan Society of Civil Engineering (JSCE), Standard Specification for Tunneling-2006: Mountain Tunnels. Tokyo, (2007)

10. Z. Bieniawski, Engineering rock mass classifications: A complete manual for engineers and geologist in mining, civil, and petroleum engineering (John Wiley and Sons, New York, 1989)

11. Tsiambaos, \& Saroglau, Bull. Eng. Geol. Environ. 69(1), 13-27 (2009)

12. Sudjatmiko, Geological Map Of The Cianjur Quadrangle, Jawa (2003)

13. P. Marinos, E. Hoek, GSI: a Geologically Friendly tool for rock mass strength estimation, in Proceeding International Conference on Geotechnical \& Geological Engineering, GeoEng2000, 1422-1442 (2000)

14. Ministry of Public Works and Public Housing, Guidelines for Excavation Planning Methods and Road Tunnel Strengthening Systems in Mixed Soil - Rock Media, 30/SE/M, (2015)

15. N. Sivakaguan, S. Shukla, B.M. Das, Rock Mechanics: An Introduction (CRC Press, 2013) 